International Journal of

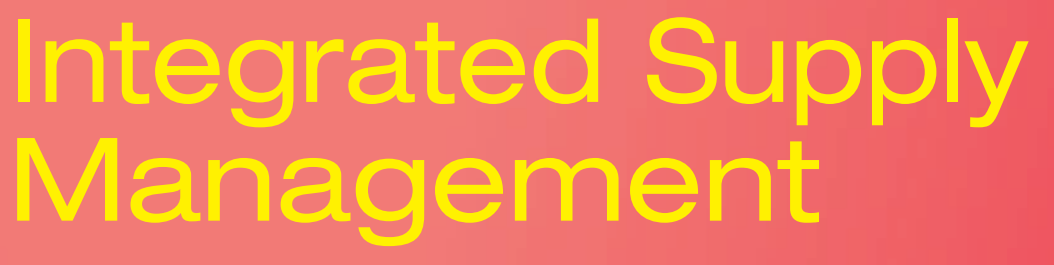




\section{Scope of the Journal}

ISSN: 1477-5360 (Print), ISSN: 1741-8097 (Online)

IJISM's thematic focus is on research that investigates and improves integration along supply chains. IJISM seeks highimpact scholarly analytical and empirical research in integrated supply management from academics and professionals. It is discipline-agnostic. Supply chain integration can be a complex and challenging imperative involving industry 4.0 ecosystems, alignment of supply markets and consumers, associated organisational changes, and the creation and management of integrative relationships in the supply chain. Substantive research that addresses such issues is solicited.

\section{Contents}

IJISM publishes original, high-quality, analytical (quantitative models), empirical (surveys and case studies) and theoretical research manuscripts (literature reviews, thought pieces) from academics and practitioners.

\section{Topics covered include:}

- Industry 4.0 and smart manufacturing/service eco-systems including blockchains, robotics, wearables, sensors, Al, data mining, additive technologies, etc. in integrated supply chains

- Global integrated supply chain design

- Purchasing and supplier coordination and relationships

- New modelling, optimisation and empirical methodologies in integrated supply chain design and management

- Risk management and resilience

- Sustainable operations and sharing and circular economies

- Lean supply managenent

- Quality management in supply chains

- Transportation and logistics

- Customer relationship, service response, demand management in supply chains

- E-commerce supply management

- Performance measurement in supply chains

\section{Not sure if this title is the one for you?}

Visit the journal homepage at www.inderscience.com/ijism where you can:

- View sample articles in full text HTML or PDF format

- Sign up for our free table of contents new issue alerts via e-mail or RSS

- View editorial board details

- Find out about how to submit your papers

- Find out about subscription options, in print, online or as part of a journals collection

You can order online at www.inderscienceonline.com or download an order form from www.inderscience.com/subform.

This title is part of the Management and Business Collection (see www.inderscience.com/mb). For library collection subscriptions or for a free institutional online trial, please contact subs@inderscience.com. 


\section{Contents}

\section{SPECIAL ISSUE: SUSTAINABLE SUPPLY CHAINS AND CIRCULAR ECONOMY}

Guest Editors: Professor Benny Tjahjono, Dr. Hendrik Reefke and Professor Nyoman Pujawan

$103 \quad$ Editorial Benny Tjahjono, Hendrik Reefke and Nyoman Pujawan

107 The impact of Industry 4.0 on sustainability and the circular economy reporting requirements

Sukhraj Singh Takhar and Kapila Liyanage

$140 \quad$ Impacts of Industry 4.0 in sustainable food manufacturing and supply chain

Olumide Olajide Ojo, Satya Shah and Alec Coutroubis

159 Circular economy business model design Arman Hakim Nasution, Mucharromatul Aula and Dewie Saktia Ardiantono

178 Drivers and barriers of consumer purchase intention of remanufactured mobile phones: a study on Indonesian consumers

Didik Wahjudi, Shu-san Gan, Yopi Yusuf Tanoto and Jerry Winata

192 Consumers' perceptions of circular economy in the hotel industry: evidence from Portugal Jorge Julião, Marcelo Gaspar and Clarisse Alemão

210 Sustainability as a driver of operational excellence - the relevance of variability in process operations

Daniela Silva and Américo Azevedo

234 Effect of corporate sustainable development on green purchasing: insights from ISO 14001 certified manufacturing companies in Malaysia Marini Nurbanum Mohamad and Charis Samuel Solomon Koilpillai

252 Factors influencing information and communication technology diffusion in Nigeria's transport logistics industry: an exploratory study Anthony Ezenwa, Anthony Whiteing, Daniel Johnson and Akunna Oledinma

277 Assessing significant factors for sustainable cold chain performance in Sri Lankan context

Keshala Wickrama Gunaratne and Pradeepa Jayaratne

302 Supply network configuration archetypes for the circular exploitation of solid waste Naoum Tsolakis, Dimitris Zissis and Jagjit Singh Srai 
Home For Authors For Librarians Orders Inderscience Online News

Home > International Journal of Integrated Supply Management

\section{International Journal of Integrated Supply Management}

(2) This journal also publishes Open Access articles

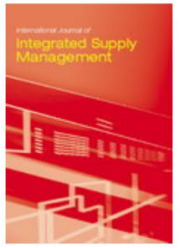

Editor in Chief

Dr. Ajay Das

ISSN online

1741-8097

ISSN print

$1477-5360$

4 issues per year

Subscription price

CiteScore 2020

\section{Scopus}

IJISM's thematic focus is on research that investigates and improves integration along supply chains. IJISM seeks high-impact scholarly analytical and empirical research in integrated supply management from academics and professionals. It is discipline-agnostic. Supply chain integration can be a complex and challenging imperative involving industry 4.0 ecosystems, alignment of supply markets and consumers, associated organisational changes, and the creation and

management of integrative relationships in the supply chain. Substantive research that addresses such issues is solicited.

About this journal Editorial board Submitting articles

\section{Honorary Editor}

- Wisner, Joel D., University of Nevada, Las Vegas, USA

\section{Editor in Chief}

Das, Ajay, Baruch College, USA

(ijism@baruch.cuny.edu)

\section{Editor}

- Ivanov, Dmitry, Berlin School of Economics and Law, Germany

\section{Advisory Board}

- Choi, Tsan-Ming (Jason), The Hong Kong Polytechnic University, Hong Kong SAR, China

- Dolgui, Alexandre, IMT Atlantique, France

- Talluri, Srinivas, Michigan State University, USA

\section{Editorial Board Members}

- Abdel-Malek, Layek, New Jersey Institute of Technology, USA

- Altay, Nezih, DePaul University, USA

- Altinoz, Cuneyt, USA

- Aydinliyim, Tolga, University of Oregon, USA

- Azadegan, Arash, Rutgers Business School - Newark and New Brunswick, USA

- Babbar, Sunil, Florida Atlantic University, USA

- Bajaj, Akhilesh, The Univerisity of Tulsa, USA

- Battini, Daria, University of Padova, Italy

- Bhutta, Khurrum, Ohio University, USA

- Brandenburg, Marcus, Flensburg University of Applied Sciences, Germany

- Calantone, Roger J., Michigan State University, USA

- Carr, Amelia, Bowling Green State University, USA

- Childerhouse, Paul, Massey University, New Zealand

- Elbert, Ralf, Technische Universität Darmstadt, Germany

- Erzurumlu, Sinan, Babson College, USA

- Fawcett, Stanley E., Weber State University, USA

- Frazzon, Enzo Morosini, Federal University of Santa Catarina, Brazil

- Geng, Qin, Kutztown University of Pennsylvania, USA

- Giannoccaro, Ilaria, Polytechnic University of Bari, Italy

- Glock, Christoph, Technische Universität Darmstadt, Germany

- Gunasekaran, Angappa, Penn State Harrisburg, USA

- Handfield, Robert, North Carolina State University, USA

- Hill, Craig A., Clayton State University, USA
Sign up for new issue alerts

Subscribe/buy articles/issues

View sample articles

Latest issue contents as RSS feed

Forthcoming articles

Journal information in easy print format (PDF)

Publishing with Inderscience:

ethical guidelines (PDF)

Recommend to a librarian (PDF)

Feedback to Edito

Find related journals

Keep up-to-date

B Our Blog

(2) Follow us on Twitter

f Visit us on Facebook

価 Our Newsletter (subscribe for free)

ה RSS Feeds

Ne New issue alerts 
- Jacobs, Mark A., University of Dayton, USA

- Jayaram, Jayanth, University of South Carolina, USA

- Kaynak, Hale, The University of Texas-Pan American, USA

- Kinra, Aseem, Universität Bremen, Germany

- Krishnan, Krishna Kumar, Wichita State University, USA

- Mahapatra, Santosh K., Clarkson University, USA

- Mahmoodi, Farzad, Clarkson University, USA

- Min, Hokey, Bowling Green State University, USA

- Mirzaei, Shokoufeh, Cal Poly Pomona, USA

- Modi, Sachin B., Wayne State University, USA

- Montabon, Frank L., lowa State University, USA

- Nair, Anand, University of South Carolina, USA

- Narayanan, Sriram, Michigan State University, USA

- Pannirselvam, Gertrude, Southern Illinois University Edwardsville, USA

- Park, Byung Joon, Singapore University of Social Science, Singapore

- Samson, Danny A., University of Melbourne, Australia

- Sanders, Nadia, Lehigh University, USA

- Schoenherr, Tobias, Michigan State University, USA

- Sokolov, Boris Vladimirovich, SPIIRAS (St. Petersburg Institute for Informatics and Automation of the

Russian Academy of Sciences), Russian Federation

- Talalayevsky, Alex, George Mason University, USA

- Tiwari, Manoj Kumar, Indian Institute of Technology, India

- Visich, John K., Bryant University, USA

- Yalaoui, Farouk, University of Technology of Troyes, France

- Zhang, Qingyu, Arkansas State University, USA

- Zhang, Yue, University of Toledo, USA 


\section{International Journal of Integrated Supply Management}

COUNTRY

United Kingdom

III Universities and research institutions in United Kingdom
SUBJECT AREA AND CATEGORY

Business, Management and Accounting

- Marketing

- Strategy and Management
PUBLISHER

Inderscience Enterprises Ltd.

ISSN

14775360,17418097

20

Journals

COVERAGE

2005-2020
INFORMATION

Homepage

How to publish in this journal

ijism@baruch.cuny.edu

SCOPE

IJISM's thematic focus is on research that investigates and improves integration along supply chains. IJISM seeks high-impact scholarly analytical and empirical research in integrated supply management from academics and professionals. It is discipline-agnostic. Supply chain integration can be a complex and challenging imperative involving industry 4.0 ecosystems, alignment of supply markets and consumers, associated organisational changes, and the creation and management of integrative relationships in the supply chain. Substantive research that addresses such issues is solicited. Topics covered include: -Industry 4.0 and smart manufacturing/service eco-systems including blockchains, robotics, wearables, sensors, Al, data mining, additive technologies, etc. in integrated supply chains -Global integrated supply chain design -Purchasing and supplier coordination and relationships -New modelling, optimisation and empirical methodologies in integrated supply chain design and management -Risk management and resilience -Sustainable operations and sharing and circular economies -Lean supply managenent -Quality management in supply chains -

Transportation and logistics -Customer relationship, service response, demand management in supply chains -E-commerce supply management Performance measurement in supply chains

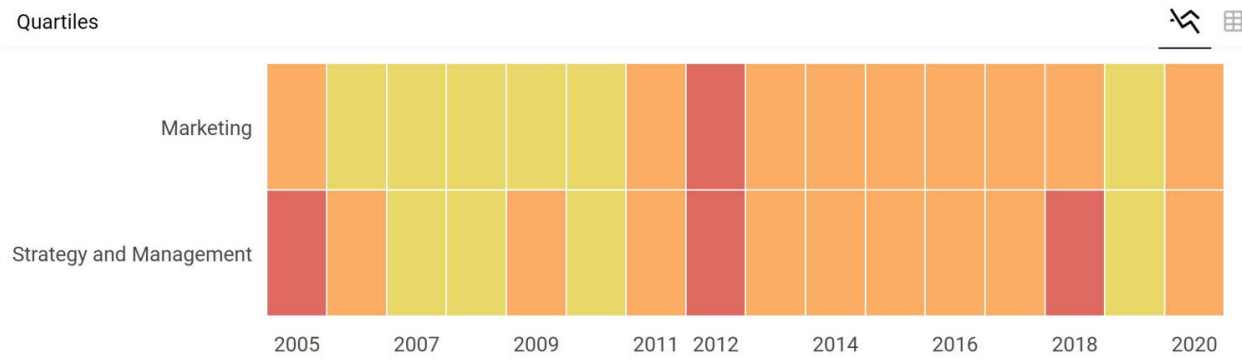


2

International Journal of Logistics Research and

Supply Chain Forum

$64 \%$

similarity similarity
$64 \%$
International Journal of

Business Performance and

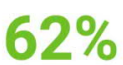

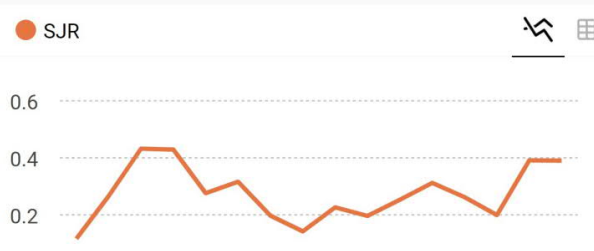

0

$20052007200920112013 \quad 2015 \quad 2017 \quad 2019$

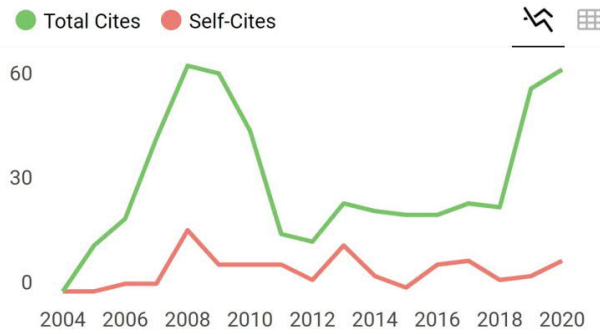

External Cites per Doc Cites per Doc ネ田

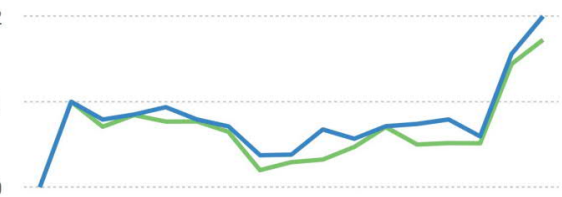

$200420062008201020122014 \quad 201620182020$

$\%$ International Collaboration
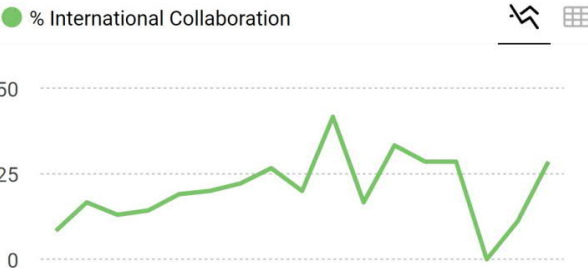

200420062008201020122014201620182020

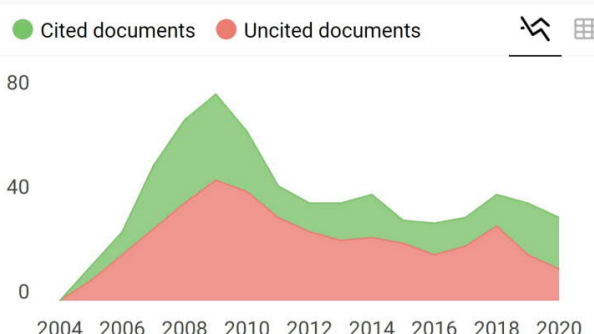

G SCImago Graphica

Explore, visually communicate and make
Total Documents 该

40

20

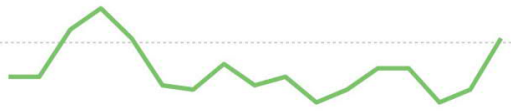

200420062008201020122014201620182020

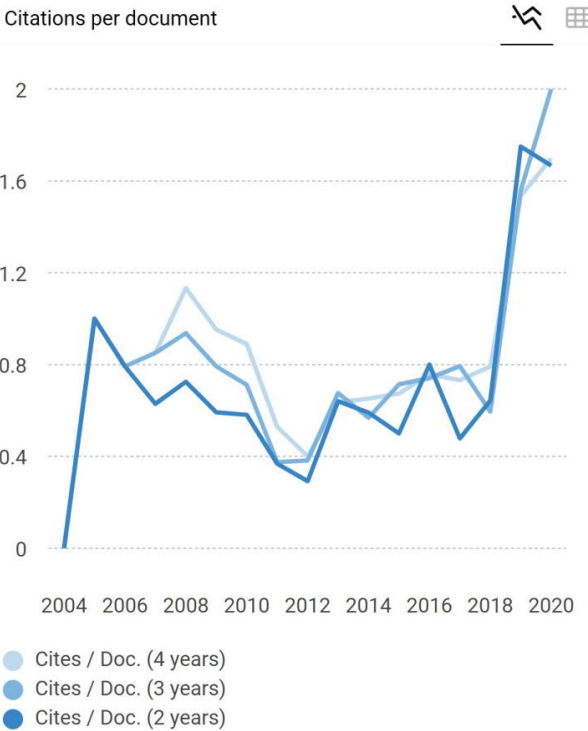

Citable documents Non-citable documents 该 80

40

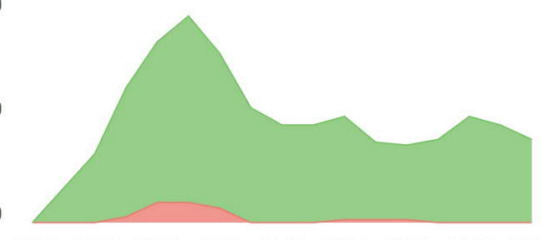

$2004200620082010201220142016 \quad 20182020$

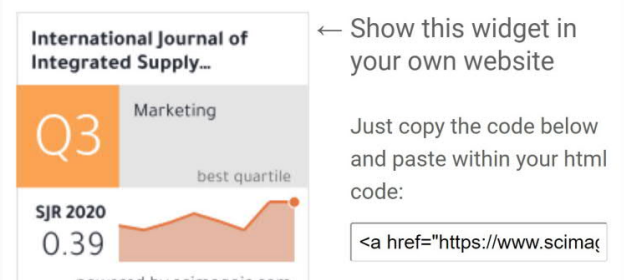




\title{
Drivers and barriers of consumer purchase intention of remanufactured mobile phones: a study on Indonesian consumers
}

\section{Didik Wahjudi*, Shu-san Gan, Yopi Yusuf Tanoto and Jerry Winata}

\author{
Mechanical Engineering Department, \\ Petra Christian University, \\ Surabaya, Indonesia \\ Email: dwahjudi@petra.ac.id \\ Email: gshusan@petra.ac.id \\ Email: yopi.tanoto@petra.ac.id \\ Email: m24414051@john.petra.ac.id \\ *Corresponding author
}

\begin{abstract}
Remanufacturing is widely practiced because it reduces landfill, saves energy, and conserves natural resources. Little effort is given to exploring the acceptance of remanufactured products, especially the short life-cycle ones. Indonesia, the fourth-largest mobile phone users, needs to tackle the vast WEEE deriving from obsolete mobile phones. This study investigates drivers and barriers of consumer purchase intention for remanufactured mobile phones. Thirteen respondents were interviewed, representing different age groups, genders, and social classes. The key drivers are the affordable price, upgraded specification, and product warranty, while the regulatory concern, trend concern, and obsolescence concern are the main barriers. Perceived quality and quality assurance can be both drivers and barriers, depending on the level. This study recommends remanufacturers to focus on providing upgraded specification at an affordable price and providing information about the remanufacturing process. This study also argues the urgency for the government to enforce rigorous regulation against counterfeit products.
\end{abstract}

Keywords: remanufacturing; mobile phone; short life-cycle product; case study; Indonesia.

Reference to this paper should be made as follows: Wahjudi, D., Gan, S-s., Tanoto, Y.Y. and Winata, J. (2020) 'Drivers and barriers of consumer purchase intention of remanufactured mobile phones: a study on Indonesian consumers', Int. J. Integrated Supply Management, Vol. 13, Nos. 2/3, pp.178-191.

Biographical notes: Didik Wahjudi is an Associate Professor in the Mechanical Engineering, Petra Christian University, Surabaya, Indonesia. He received his Bachelor's from the Mechanical Engineering Department, Sepuluh Nopember Institute of Technology (ITS), Surabaya, Indonesia. He received his Master's of Science from the University of Iowa and Master's of Engineering from the Texas A\&M University, USA. He completed his PhD from the Industrial Engineering Department, ITS, Surabaya, Indonesia. His research interests are in the area of quality management, Lean Six Sigma, and remanufacturing. He has published his articles in the International Journal of Productivity and Quality Management and International Journal of Business and Society. 
Shu-san Gan is an Associate Professor at the Petra Christian University, Mechanical Engineering Department. She received her Bachelor's in Mathematics from the Sepuluh Nopember Institute of Technology (ITS), Surabaya, Indonesia, MSc in Applied Mathematics from the Michigan State University, USA, and $\mathrm{PhD}$ in Industrial Engineering from the ITS. She has published articles about pricing decisions in several reputable journals, namely the International Journal of Production Economics, Operations Research Perspectives, and Operations and Supply Chain Management.

Yopi Yusuf Tanoto is a Lecturer in the Mechanical Engineering, Petra Christian University, Surabaya, Indonesia. He received his Bachelor's from the Mechanical Engineering Department, Petra Christian University, Surabaya, Indonesia. He received his Master's from the Mechanical Engineering Department, Sepuluh Nopember Institute of Technology (ITS), Surabaya, Indonesia. His research interests are in the areas of rapid prototyping and optimisation in manufacturing. He has published his articles in the Journal of Telecommunication, Electronic and Computer Engineering and ARPN Journal of Engineering and Applied Sciences.

Jerry Winata is an alumnus of Petra Christian University, Surabaya, Indonesia. $\mathrm{He}$ received his Bachelor's degree from the Mechanical Engineering Department, where he worked under the supervision of Dr. Wahjudi in his final project research. His research interests are in the areas of remanufacturing and material science.

This paper is a revised and expanded version of a paper entitled 'Drivers and barriers of consumer purchase intention of remanufactured mobile phones: a study on Indonesian consumers' presented at the 8th International Conference on Operations and Supply Chain Management (OSCM 2018), Cranfield, UK, 9-12 September 2018.

\section{Introduction}

Remanufacturing develops into a very big business in the USA and some European countries (Gaur et al., 2015; Parker et al., 2015). However, it is still in its embryonic stages in many emerging and developing countries. Several studies are conducted to identify driving factors and barriers of remanufacturing business. Environmental consciousness level, individual values, and socio-cultural norms are identified to be the major drivers of consumer purchase intentions for remanufactured products (Gaur et al., 2015). van Weelden et al. (2016) identify misconception of remanufactured products, lack of awareness, lack of availability, and lack of the thrill of newness to be the barriers for remanufactured mobile phones to be considered for purchase consideration. Mobile phone experiences end-of-use after 18 months or less because of functional and psychological obsolescence (Franke et al., 2006; Guide and Van Wassenhove, 2009). Indonesia has the fourth-largest mobile phone users in the world (Central Intelligence Agency, 2016). While studies indicate that the biggest opportunity for remanufacturing is for high added-value, durable, and technologically stable products (Chapman et al., 2010; Lund, 1984), the rapid generation of WEEE caused by the usage of mobile phone presents a challenging problem. While Indonesia is not known as an environmentally-conscious society, it is critical to investigate the prospect of mobile 
phone remanufacturing business in Indonesia. This study aims to investigate the drivers and barriers of consumer purchase intention of remanufactured mobile phones in Indonesia. The rest of the paper is organised as follows. Literature review on the closed-loop supply chain (CLSC), remanufacturing of mobile phones, and consumer acceptance of remanufactured products is provided in Section 2. Section 3 describes the research methodology for this research. Section 4 provides results and discussion of key findings. Finally, Section 5 presents conclusions, limitations, and recommendations for future research.

\section{Literature review}

\subsection{Closed-loop supply chain}

The increased use of mobile phones creates a vast production of WEEE. At the end-of-use, a mobile phone can go through an open-loop supply chain or CLSC. Thus, in the open-loop supply chain, mobile phones can be either landfilled or incinerated. In a CLSC, mobile phones are taken back and reused as products, components, parts, and materials. Lund (1984) classifies efforts to retain the value of products into five categories, as illustrated in Figure 1. Throughout this paper, the following definitions provided by Ijomah et al. (1999) and Lund (1984) are used.

- Repair: a process of bringing a damaged product back to a functional condition by the same user.

- Reuse: a process of using a functional product by another user after the product no longer satisfies the first user.

- Refurbishing/reconditioning: a process of restoring a product to a satisfactory state that is not necessarily the same as the new product.

- Remanufacturing: a process of restoring a product to its original specification or better and provided with a warranty that is comparable with the warranty of the new product.

- Recycling: a process of recovering material value by transforming the product into a material with the same quality or lower.

CLSC gains its popularity after governments in developed countries enforce take-back regulation because of growing concern over some environmental issues. Coupled with the escalation of customers' environmental awareness, this regulation effectively drives manufacturers to reduce the amount of waste. In addition to the take-back program, manufacturers acquire end-of-use or end-of-life products through several other channels such as off-lease or off-rent return, broken product return, and buy-back program (Thierry et al., 1995).

Indonesia is a developing country that needs to solve many environmental issues. Most of the Indonesian residents do not have enough awareness of environmental problems such as global warming, ozone layer depletion, water pollution, and acid rain (Sudarmadi et al., 2001). Even though reconditioning and remanufacturing businesses become popular among small and medium-sized enterprises (SMEs) in Indonesia (Fatimah et al., 2013), their main motivation is merely short-term profit. Kamigaki et al. 
(2017) report that companies are more interested to do reconditioning business compared to remanufacturing, although remanufacturing business is more profitable and more environmentally friendly. The value of remanufactured photocopiers is two and a half times more than the refurbished ones. The reason behind this situation is that reconditioning business offer faster turnover than remanufacturing business.

Figure 1 The five categories of CLSC

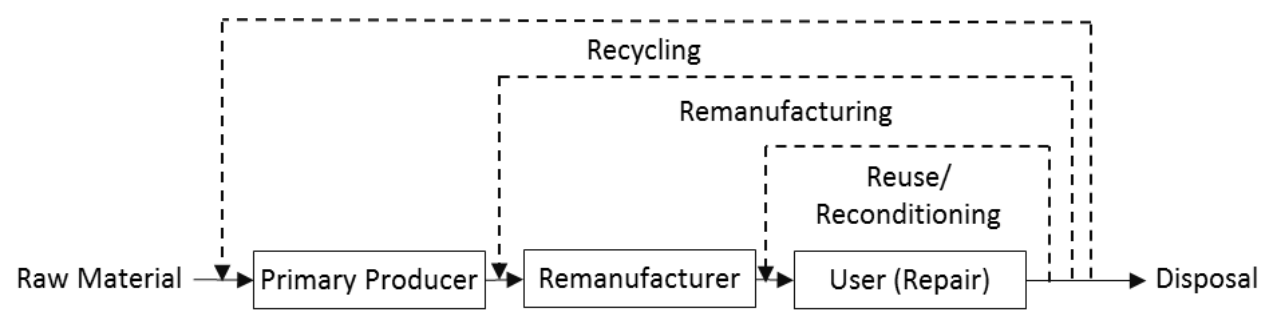

\subsection{Remanufacturing of mobile phones}

Remanufacturing gets a lot of attention from researchers and academia because of its unique characteristics. Reuse is limited to a functional phone, while refurbishing or reconditioning can only be done on handsets that need little processing such as replacement of worn or damaged parts, resurfacing and repainting (Rathore et al., 2011). The simple operations make refurbishing business attractive for resellers, not OEMs (Geyer and Blass, 2010). Therefore, refurbished mobile phones do not usually come with a warranty. In addition, refurbished mobile phones have diverse qualities because of the nature of the operations and refurbishing operators. These conditions limit the distribution of refurbished mobile phones. On the other hand, remanufacturing is performed by OEMs and independent remanufacturers (Parker et al., 2015). The fact that remanufactured products come with a warranty and have gone through a stricter process causes remanufactured products can be distributed in a wider market, even in the overseas market (Chapman et al., 2010). In developing and emerging countries where remanufacturing is still in the embryonic stage, confusion between remanufacturing and refurbishing often occurs. Gaur et al. (2015) identify two characteristics that distinguish remanufacturing from refurbishing. First, the disassembly level of remanufacturing is at the component level, while it is at the module level for refurbishing. Second, remanufactured mobile phones come with a warranty, which refurbished ones do not have.

\subsection{Consumer acceptance of remanufactured products}

Several studies have explored the consumer acceptance of remanufactured products. Two indicators that are often used to indicate consumer acceptance are willingness-to-pay (WTP) and purchase intention. Some authors conduct studies on the WTP for remanufactured products. Guide and Li (2010) identify that WTP for remanufactured products is less than that for the new products both for consumer and commercial products. Atasu et al. (2010) argue that WTP for remanufactured consumer products are $15 \%$ lower than that for the new products, while the WTP for 
remanufactured commercial products is only $10 \%$ less than that for the new ones. However, Michaud and Llerena (2011) find that the lower WTP for remanufactured products only happens when the consumers are not informed about the environmental benefits of the remanufactured products. Once they are informed about the environmental benefit, the consumers are willing to pay the same price as that for the new products. Atasu et al. (2010) classify the market into three consumer groups, i.e., newness-conscious consumers, functionality-oriented consumers, and green consumers. Consumers that are newness-conscious will not consider remanufactured products unless they are offered at a very low price compared to the new ones. Functionality-oriented consumers will choose remanufactured products if they are offered at a slightly lower price. This consumer group perceives the value of remanufactured products is very similar to that of the new ones. On the other hand, green consumers will prefer remanufactured products even though the price is more expensive because they are more environmentally-friendly (Atasu et al., 2010). Yet, Michaud and Llerena (2011) do not identify the existence of consumers who are willing to pay a premium for environmentally-friendly products.

Purchase intention for remanufactured products has been studied by some researchers. Wang et al. (2013), conducting empirical studies on remanufactured automobile parts, identify that purchase intention is directly influenced by purchase attitude, perceived behavioural control, subjective norm, and product knowledge. They find an anomaly in the negative impact of product knowledge on purchase intention. In addition, they indicate that purchase intention for remanufactured automobile parts is also influenced indirectly by perceived benefit, perceived risk, and product knowledge. Jimenez-Parra et al. (2014) conduct a study to investigate factors that affect purchase intention for remanufactured laptops. They identify that purchase attitude, subjective norm, price, environmental factors, design, and brand reputation are positively influenced by the purchase intention for remanufactured laptops. Gaur et al. (2015) identify six motives that influence the purchase intention for remanufactured products, i.e., environmental consciousness, individual values and attitudes, utilitarian buying behaviour, hedonistic buying behaviour, nature of the product, and socio-cultural norms. Wang and Hazen (2016) argue the importance of product knowledge that consists of quality knowledge, cost knowledge, and green knowledge on the purchase intention for remanufactured products. They identify that both perceived value and perceived risk are predominantly influenced by quality knowledge, followed by cost knowledge, while green knowledge only contributes to improving the perceived value of the products. The trade-off between perceived value and perceived risk decides how much intention the consumer has to purchase the remanufactured product. Sharma et al. (2016) conduct a survey to identify drivers and roadblocks for remanufacturing business. They find competitive pricing, the best way of product recovery, and positive societal concerned image to be the main financial, environmental, and social driver, respectively. Quality concern due to lack of standardisation, awareness, and availability becomes the key barrier for remanufacturing business in India (Sharma et al., 2016). A recent survey conducted by these authors on mobile phone consumers indicates that purchase intention is directly influenced by product knowledge and purchase attitude (Wahjudi et al., 2018). Purchase intention is indirectly influenced by perceived benefit and perceived risk through purchase attitude (Wahjudi et al., 2018). 


\section{Research methodology}

This study used a case study method to explore the drivers and barriers of consumer purchase intention for remanufactured mobile phones. A case study protocol was developed to guide the interview. The protocol consisted of questions about demographic information of respondents, the familiarity with remanufactured products, personal preference on mobile phones, perceived benefits, perceived risks, and their purchase intention for remanufactured mobile phones.

Respondents interviewed in this study were selected using the purposeful sampling technique (Coyne, 1997). Demographic factors such as social class, age, and gender were suspected to affect the purchase intention because of the very people-related characteristics of this study (Sandelowski, 1995). Therefore, it was desired to have several samples from every social class, age, and gender group. The diversity of background was designed to provide a more diverse perspective in this case study. Thirteen respondents were interviewed to represent different genders, age groups, and social classes. It was realised that it would be more ideal to conduct interviews in different locations in Indonesia. However, instead of conducting the interviews in a different location in Indonesia, we interviewed respondents from different urban and rural areas in Indonesia that lived in Surabaya. Each interview took about 30 to 40 minutes. The resulted audio record was transcribed and coded. In this study, we cannot interview actual remanufactured mobile phone buyers because there are no remanufactured mobile phones available in Indonesia. To resolve this problem, the respondents were given a short description of what remanufactured mobile phone is, especially to those who never hear about remanufactured products. Table 1 provides the demographics of respondents.

Table 1 Demographics of respondents

\begin{tabular}{lccc}
\hline Respondent & Age & Gender & Social class \\
\hline $\mathrm{C} 1$ & $\leq 22$ years & Male & Middle \\
$\mathrm{C} 2$ & $\leq 22$ years & Female & Middle \\
$\mathrm{C} 3$ & Male & Upper middle \\
$\mathrm{C} 4$ & $\leq 22$ years & Female & Upper middle \\
$\mathrm{C} 5$ & $\leq 22$ years & Female & Middle \\
$\mathrm{C} 6$ & $>22$ years & Male & Lower middle \\
$\mathrm{C} 7$ & $>22$ years & Male & Upper middle \\
$\mathrm{C} 8$ & $>22$ years & Male & Middle \\
$\mathrm{C} 9$ & $>22$ years & Male & Middle \\
$\mathrm{C} 10$ & $>22$ years & Male & Lower middle \\
$\mathrm{C} 11$ & $\leq 22$ years & Female & Lower middle \\
$\mathrm{C} 12$ & $\leq 22$ years & Female & Poor \\
$\mathrm{C} 13$ & $>22$ years & Female & Upper middle \\
\hline
\end{tabular}




\section{Results and discussion}

The transcribed record was coded by one research team member using NVivo 10 software to identify recurring themes. To improve the reliability of the study the resulted codes were presented to and discussed with other research team members in the research group meeting. Eighteen codes were discovered and classified into four driving factors and three inhibiting factors. The driving factors with their supporting codes and respective quotations are given in Table 2. Table 3 gives the list of inhibiting factors with their supporting codes and respective quotations.

\subsection{Drivers of purchase intention of remanufactured mobile phones}

Four driving factors are identified in this study, i.e., environmental benefit, financial benefit, quality, benefit, and social benefit. Nearly every respondent mentions affordable prices as the main driver to consider purchasing remanufactured mobile phones. In addition to driving the purchase intention of remanufactured mobile phones, the affordable price also provides stronger market competition to control the ever-increasing price of new mobile phones. Quality benefit has four coded themes, i.e., upgraded specification, perceived quality, quality assurance, and product warranty. Together with affordable price, the upgradeable specification is the main appeal for purchasing remanufactured mobile phones. Positive perceived quality and quality assurance improve the purchase intention, while product warranty can be considered as a basic factor as in the Kano model (Kano et al., 1984). The existence of a product warranty is important to ensure service reliability amid a lack of confidence in the product quality.

Mobile phone remanufacturing provides a social benefit because it allows consumers from the middle to lower middle classes to buy top brand mobile phones.

"It creates a chance for the middle to lower middle classes to buy the top brand mobile phones."

These consumer segment usually looks for cheap mobile phones that have good features and performance. In addition, most respondents indicate that remanufactured mobile phones are suitable for Indonesia that has a vast population and the majority of its population is from the middle and lower-middle classes. All respondents confirm the environmental benefit that comes from the reduction of e-waste and conservation of natural resources.

\subsection{Barriers of purchase intention of remanufactured mobile phones}

Financial risk, quality risk, and social risk are the three risks identified in this study. Financial risk comes from obsolescence concern and regulatory concern. Some respondents argue that remanufactured mobile phones may become obsolete quickly. This situation will cause scarcity of replacement parts when their remanufactured mobile phones need repair and replacement of parts. The other concern deals with respect to poor legal consumer protection. In the absence of adequate legal protection, consumers may receive used mobile phones instead of remanufactured ones, especially when they purchase from online stores and unauthorised retailers. 
Table 2 List of drivers with their respective codes and quotations

\begin{tabular}{|c|c|c|}
\hline Drivers & Codes & Quotation from interviews \\
\hline \multirow{5}{*}{$\begin{array}{l}\text { Environmental } \\
\text { benefit }\end{array}$} & Eco-consciousness & Remanufacturing reduces electronic waste. \\
\hline & & $\begin{array}{l}\text { There are uniqueness and pride in using remanufactured } \\
\text { products. }\end{array}$ \\
\hline & Natural resources & Remanufacturing does not exploit the nature excessively. \\
\hline & concern & It conserves the environment sufficiently. \\
\hline & & It supports the promotion of green products. \\
\hline \multirow{5}{*}{$\begin{array}{l}\text { Financial } \\
\text { benefit }\end{array}$} & Affordable price & The price is more affordable. \\
\hline & & The price is very low. \\
\hline & & $\begin{array}{c}\text { We can have it at a cheap price, but it has the features of } \\
\text { new phones. }\end{array}$ \\
\hline & & $\begin{array}{l}\text { The price is affordable, but the performance is almost the } \\
\text { same as the new ones. }\end{array}$ \\
\hline & Market competition & $\begin{array}{l}\text { It's good for business competition because mobile phones' } \\
\text { price is increasing. }\end{array}$ \\
\hline \multirow[t]{12}{*}{$\begin{array}{l}\text { Quality } \\
\text { benefit }\end{array}$} & $\begin{array}{l}\text { Upgraded } \\
\text { specification }\end{array}$ & $\begin{array}{l}\text { The specification can be upgraded; performance is better } \\
\text { than the used ones. }\end{array}$ \\
\hline & & The specification is the most important. \\
\hline & & It has good features. \\
\hline & & It has features of new phones at a cheap price. \\
\hline & Perceived quality & $\begin{array}{l}\text { The quality is still good, not much different from the new } \\
\text { one; the outside case is flawless. }\end{array}$ \\
\hline & & $\begin{array}{c}\text { In terms of durability, it isn't much different from the new } \\
\text { ones. }\end{array}$ \\
\hline & & $\begin{array}{l}\text { Other people cannot distinguish remanufactured } \\
\text { [mobile phones from the new ones]. }\end{array}$ \\
\hline & Quality assurance & $\begin{array}{l}\text { The product is repaired by a professional, so it can be } \\
\text { trusted. }\end{array}$ \\
\hline & & There is a quality inspection, so it is more trusted. \\
\hline & & $\begin{array}{l}\text { The remanufacturing is done by the factory and it comes } \\
\text { with a warranty, so it is trusted. }\end{array}$ \\
\hline & & It has been officially fixed so it's should be reliable. \\
\hline & Product warranty & It is reliable because it comes with a warranty. \\
\hline \multirow[t]{5}{*}{ Social benefit } & Social expectation & $\begin{array}{c}\text { Very accommodating and suitable for Indonesian people } \\
\text { who are looking for cheap mobile phones that have good } \\
\text { features and performance. }\end{array}$ \\
\hline & & $\begin{array}{l}\text { In Indonesia people are prioritizing prices rather than } \\
\text { trends. }\end{array}$ \\
\hline & & $\begin{array}{l}\text { It is suitable for consumptive people who often change } \\
\text { mobile phones. }\end{array}$ \\
\hline & & $\begin{array}{l}\text { It creates a chance for the middle to lower middle classes } \\
\text { to buy the top brand mobile phones. }\end{array}$ \\
\hline & & $\begin{array}{l}\text { It is suitable for Indonesia because it has many middle to } \\
\text { lower-middle-class people. }\end{array}$ \\
\hline
\end{tabular}


Quality risk consists of quality assurance, perceived quality, and lack of OEM's support. Several respondents expressed their doubts about the quality assurance of remanufactured mobile phones. This is reinforced by the lack of support from mobile phones' producers. Respondents are also afraid that remanufactured mobile phones do not have the promised quality, which is as good as new products. This situation may be caused by the fact that remanufacturing is still not widely known to many Indonesians.

Table 3 List of barriers with their respective codes and quotations

\begin{tabular}{|c|c|c|}
\hline Factors & Codes & Quotation from interviews \\
\hline \multirow[t]{4}{*}{$\begin{array}{l}\text { Financial } \\
\text { risk }\end{array}$} & $\begin{array}{l}\text { Obsolescence } \\
\text { concern }\end{array}$ & Replacement parts are unavailable because of obsolescence. \\
\hline & $\begin{array}{l}\text { Regulatory } \\
\text { concern }\end{array}$ & $\begin{array}{l}\text { Fear of buying used mobile phones, not the remanufactured ones. } \\
\text { I do not know the components inside, good or not, original or } \\
\text { counterfeit. }\end{array}$ \\
\hline & & Online stores may sell counterfeit products. \\
\hline & & I am afraid to buy it from an unauthorized retailer. \\
\hline \multirow[t]{10}{*}{$\begin{array}{l}\text { Quality } \\
\text { risk }\end{array}$} & $\begin{array}{c}\text { Quality } \\
\text { assurance }\end{array}$ & $\begin{array}{c}\text { I am not convinced of the quality. Perhaps used mobile phone has } \\
\text { better quality. }\end{array}$ \\
\hline & & There is no trust in remanufactured products. \\
\hline & & $\begin{array}{l}\text { I am afraid there is a broken part that is not replaced by the new one, } \\
\text { but it is repaired partially. }\end{array}$ \\
\hline & & I am afraid there is unrepaired damage. \\
\hline & $\begin{array}{l}\text { Perceived } \\
\text { quality }\end{array}$ & $\begin{array}{l}\text { I am afraid that the mobile phone fails, and I need to go to the service } \\
\text { centre frequently. }\end{array}$ \\
\hline & & The product may fail again and unrepairable. \\
\hline & & Product quality is not as expected. \\
\hline & & Not every part can be upgraded. \\
\hline & & Electronic products have a limited lifespan. \\
\hline & $\begin{array}{l}\text { Lack of } \\
\text { OEM's support }\end{array}$ & $\begin{array}{l}\text { There is no statement from the manufacturer that they support } \\
\text { remanufacturing. }\end{array}$ \\
\hline \multirow{10}{*}{$\begin{array}{l}\text { Social } \\
\text { risk }\end{array}$} & Prestige & There is a sense of shame to buy a remanufactured mobile phone. \\
\hline & cern & It is more prestigious to buy new mobile phone, even the cheap one. \\
\hline & & Indonesian people tend to buy new HP and pursue prestige. \\
\hline & & Indonesian people tend to be consumptive and brand-conscious. \\
\hline & $\begin{array}{l}\text { Subjective } \\
\text { norm }\end{array}$ & $\begin{array}{c}\text { There isn't any friend that recommends remanufactured mobile } \\
\text { phone. }\end{array}$ \\
\hline & Public opinion & $\begin{array}{c}\text { The society's viewpoint and public confidence in remanufactured } \\
\text { mobile phones is still low. }\end{array}$ \\
\hline & Trend concern & The model is outdated. \\
\hline & & $\begin{array}{l}\text { Middle to upper-middle-class people tend to follow the new model in } \\
\text { terms of phone weight, size, etc. }\end{array}$ \\
\hline & & Later model is much slimmer, the older model is bulkier. \\
\hline & & $\begin{array}{l}\text { People tend to follow the trend, models of mobile phone change } \\
\text { quickly. }\end{array}$ \\
\hline
\end{tabular}


The third kind of risk is a social risk. Several respondents indicated that remanufactured mobile phone is not a prestigious product. They argue that middle and upper-middle-class consumers tend to be consumptive and very brand-conscious to show their prestige. Furthermore, the lack of a recommendation from friends and other influential people around them will prohibit them from purchasing remanufactured mobile phones. The fact that a mobile phone not only serves as a communication device but also serves as a fashion item, encourages mobile phone users to change their mobile phones frequently to follow the trend. Guide and Van Wassenhove (2009) claim that mobile phone users change their devices every year.

Table 4 Mapping of respondents with their purchase attitude, purchase intention, and their reasons

\begin{tabular}{lccc}
\hline Respondent & $\begin{array}{c}\text { Purchase } \\
\text { attitude }\end{array}$ & $\begin{array}{c}\text { Purchase } \\
\text { intention }\end{array}$ & Reasons \\
\hline C1 & Interested & No & Quality assurance, regulatory concern \\
C2 & Interested & Yes & $\begin{array}{c}\text { Upgraded specification, affordable price, perceived } \\
\text { quality }\end{array}$ \\
C3 & Interested & Yes & Affordable price, upgraded specification \\
C4 & Interested & No & Perceived quality, quality assurance \\
C5 & Interested & No & Perceived quality, obsolescence concern \\
C6 & Interested & Yes & Upgraded specification, perceived quality \\
C7 & Interested & No & Perceived quality, regulatory concern \\
C8 & Interested & Yes & Upgraded specification, affordable price, perceived \\
& quality, quality assurance \\
C9 & Not interested & No & Quality assurance, trend concern \\
C10 & Interested & Yes & Affordable price, perceived quality, product \\
& & & warranty \\
C11 & Interested & No & Regulatory concern, perceived quality \\
C12 & Interested & No & Perceived quality, regulatory concern \\
C13 & Not interested & No & Perceived quality, quality assurance, regulatory \\
& & & concern \\
\hline
\end{tabular}

Table 4 presents the mapping of each respondent with their purchase attitude, purchase intention, and the reasons. Out of 13 respondents, only eleven of them have the interest to purchase remanufactured mobile phones. The reasons why two respondents do not have the interest to purchase are low perceived quality, low trust on quality assurance, trend concern, and regulatory concern. Respondent C9 is still unsure of the quality of remanufactured products because he is not familiar with this product. He also thinks that remanufactured mobile phones are outdated because of the fast-changing trend of mobile phone models. Respondent $\mathrm{C} 13$ is afraid to purchase a remanufactured mobile phone because:

"Remanufactured mobile phones may fail again at any time and unrepairable."

She also expresses concern about the quality assurance of process, whether the defective parts will be replaced by new parts or partially repaired. The other concern is regarding the product regulation. She fears about buying used mobile phones, instead of the remanufactured ones. 
Among respondents that express positive purchase attitude towards remanufactured mobile phones, only five of them have purchase intention when remanufactured mobile phones become available. Upgraded specification, affordable price, and product warranty improve the consumer purchase intention, while the regulatory concern, trend concern, and obsolescence concern diminish the purchase intention. Perceived quality and process quality assurance can improve or reduce consumer purchase intention. If respondents have a high perceived quality level and high trust in the quality assurance of process, they will have strong purchase intention, and vice versa.

\subsection{Discussion of findings}

This study aims to investigate drivers and barriers of consumer purchase intention of remanufactured mobile phones in Indonesia. The drivers can be categorised into the financial benefit, quality benefit, social benefit, and environmental benefit, while the identified barriers are the financial risk, quality risk, and social risk. The main financial benefit is the affordable price of remanufactured mobile phones. The main quality benefit that improves consumer purchase intention is upgraded specification. However, the contribution of the above benefits will be inadequate if the perceived quality and consumers' trust in the process quality assurance are low. Furthermore, respondents indicate a regulatory concern, trend concern, and obsolescence concern are the main barriers for consumer purchase intention of remanufactured mobile phones. Even though respondents acknowledge the environmental benefit of remanufacturing, this benefit does not play a significant impact on purchase intention.

Familiarity with remanufacturing, especially with remanufacturing of mobile phones plays a crucial role in developing purchase intention. In this study, there is a big discrepancy among respondents in terms of perceived quality and trust, which results in some respondents have adequate purchase intention and other respondents do not have the intention to purchase remanufactured mobile phones. This finding is in line with the finding of van Weelden et al. (2016) that claims product familiarity reduces perceived risk in purchasing remanufactured mobile phones. In addition, they claim users that have less confidence in their own judgment about the product quality tend to perceive a higher level of risk. On the other hand, van Weelden et al. (2016) identify warranty and service to be key determinants of the perceived risk-benefit balance when considering a remanufactured mobile phone. Our study indicates product warranty play a minor role in purchasing decision. This difference may be caused by the different settings between our study and their study. Their study is conducted in the Dutch market, where consumers can find real remanufactured products, while our study is conducted in Surabaya, Indonesia, where most people do not know what remanufactured product is.

The attractiveness of affordable price in this study is also in line with the study of van Weelden et al. (2016). Their study indicates that cheap price may have a detrimental impact as well, in that the consumers equate cheap price with low quality. In our study, affordable price does not have a strong impact on a certain group of consumers, especially those that focus on the trend. The other finding that is not identified by van Weelden et al. (2016) is the impact of the upgraded specification. Most of our respondents identify upgraded specification, besides affordable price, as the main appeal of remanufactured mobile phones. This difference may be caused by the fact that remanufactured phones available in Dutch market do not have upgraded features. This study also identifies the importance of strict and clear regulation that can protect the 
rights of consumers. This factor is not really emphasised in the study of van Weelden et al. (2016). Perhaps the fear of counterfeit products is not as critical as in the Indonesian market.

\section{Conclusions, implications, and recommendations for future research}

This study aims to identify drivers and barriers of consumer purchase intention of remanufactured mobile phones. Through in-depth interviews with thirteen respondents, our study identifies upgraded specification, affordable price, and product warranty to be the drivers of consumer purchase intention of remanufactured mobile phones, while the regulatory concern, trend concern, and obsolescence concern diminish the purchase intention. High perceived quality and high trust in the process quality assurance can improve consumer purchase intention and vice versa. This study also indicates that remanufactured mobile phones have a strong appeal to consumers that focus on affordable price and upgraded features. Consumers that focus on product newness will not be interested to purchase remanufactured mobile phones.

The managerial implication of this study is that remanufacturer should focus on providing phones with upgraded specification at an affordable price. The other important thing for phone remanufacturer is to provide information on how the remanufacturing process is done to their prospective consumers. The more familiar the consumers with the process, the smaller their perceived risk will be, which in turn it will increase their purchase intention. It is very urgent that the government impose strict regulation that protects consumers' rights. Otherwise, the remanufacturing business will not flourish in Indonesia.

There are two research limitations that we identify. First, this study was not conducted in the real market setting as in van Weelden et al. (2016). This is due to the unavailability of real remanufactured mobile phones in Indonesia. Second, we do not claim that the list of drivers and barriers is exhaustive because we did not collect enough respondents until the list saturates.

Our recommendation for future research is to continue this study with a survey to identify the contribution of each factor to the purchase intention.

\section{References}

Atasu, A., Guide Jr., V.D.R. and Van Wassenhove, L.N. (2010) 'So what if remanufacturing cannibalizes my new product sales?', California Management Review, Vol. 52, No. 2, pp.56-76.

Central Intelligence Agency (2016) The World Factbook: Telephones - Mobile Cellular [online] https://www.cia.gov/library/publications/the-world-factbook/rankorder/2151rank.html (accessed 18 June 2018).

Chapman, A., Bartlett, C., McGill, I., Parker, D. and Walsh, B. (2010) Remanufacturing in the UK: a Snapshot of the UK Remanufacturing Industry, Centre for Remanufacturing \& Reuse, Aylesbury, UK.

Coyne, I.T. (1997) 'Sampling in qualitative research. Purposeful and theoretical sampling; merging or clear boundaries?', Journal of Advanced Nursing, Vol. 26, No. 3, pp.623-630. 
Fatimah, Y.A., Biswas, W., Mazhar, I. and Islam, M.N. (2013) 'Sustainable manufacturing for Indonesian small- and medium-sized enterprises (SMEs): the case of remanufactured alternators', Journal of Remanufacturing, Vol. 3, No. 6, pp.1-11.

Franke, C., Basdere, B., Ciupek, M. and Seliger, S. (2006) 'Remanufacturing of mobile phones capacity, program and facility adaptation planning', Omega, Vol. 34, No. 6, pp.562-570.

Gaur, J., Amini, M., Banerjee, P. and Gupta, R. (2015) 'Drivers of consumer purchase intentions for remanufactured products: a study of Indian consumers relocated to the USA', Qualitative Market Research: An International Journal, Vol. 18, No. 1, pp.30-47.

Geyer, R. and Blass, V.D. (2010) 'The economics of cell phone reuse and recycling', The International Journal of Advanced Manufacturing Technology, Vol. 47, No. 5, pp.515-525.

Guide Jr., V.D.R. and Li, J. (2010) 'The potential for cannibalization of new products sales by remanufactured products', Decision Sciences, Vol. 41, No. 3, pp.547-572.

Guide, V.D.R. and Van Wassenhove, L.N. (2009) 'The evolution of closed-loop supply chain research', Operations Research, Vol. 57, No. 1, pp.10-18.

Ijomah, W.L., Bennett, J.P. and Pearce, J. (1999) 'Remanufacturing: evidence of environmental conscious business practice in UK', Proceedings First International Symposium on Environmentally Conscious Design and Inverse Manufacturing, IEEE, Tokyo, Japan.

Jimenez-Parra, B., Rubio, S. and Vicente-Molina, M-A. (2014) 'Key drivers in the behavior of potential consumers of remanufactured products: a study on laptops in Spain', Journal of Cleaner Production, Vol. 85, No. 1, pp.488-496.

Kamigaki, K., Matsumoto, M. and Fatimah, Y.A. (2017) 'Remanufacturing and refurbishing in developed and developing countries in Asia - a case study in photocopiers', The 24th CIRP Conference on Life Cycle Engineering.

Kano, N., Seraku, N., Takahashi, F. and Tsuji, S-i. (1984) 'Attractive quality and must-be quality', Journal of the Japanese Society for Quality Control, Vol. 14, No. 2, pp.147-156.

Lund, R.T. (1984) Remanufacturing: the Experience of the United States and Implications for Developing Countries, The World Bank, Washington, DC.

Michaud, C. and Llerena, D. (2011) 'Green consumer behaviour: an experimental analysis of willingness to pay for remanufactured products', Business Strategy and the Environment, Vol. 20, No. 6, pp.408-420.

Parker, D., Riley, K., Robinson, S., Symington, H., Tewson, J., Jansson, K., Ramkumar, S. and Peck, D. (2015) Remanufacturing Market Study, Oakdene Hollins, Aylesbury, UK.

Rathore, P., Kota, S. and Chakrabarti, A. (2011) 'Sustainability through remanufacturing in India: a case study on mobile handsets', Journal of Cleaner Production, Vol. 19, No. 15, pp.1709-1722.

Sandelowski, M. (1995) 'Sample size in qualitative research', Research in Nursing \& Health, Vol. 18, No. 2, pp.179-183.

Sharma, V., Garg, S.K. and Sharma, P.B. (2016) 'Identification of major drivers and roadblocks for remanufacturing in India', Journal of Cleaner Production, Vol. 112, No. 3, pp.1882-1892.

Sudarmadi, S., Suzuki, S., Kawada, T., Netti, H., Soemantri, S. and Tugaswati, A.T. (2001) 'Survey of perception, knowledge, awareness, and attitude in regard to environmental problems in a sample of two different social groups in Jakarta, Indonesia', Environment, Development and Sustainability, Vol. 3, No. 2, pp.69-183.

Thierry, M., Salomon, M., Van Nunen, J. and Van Wassenhove, L. (1995) 'Strategic issues in product recovery management', California Management Review, Vol. 37, No. 2, pp.114-136.

van Weelden, E., Mugge, R. and Bakker, C. (2016) 'Paving the way towards circular consumption: exploring consumer acceptance of refurbished mobile phones in the Dutch market', Journal of Cleaner Production, Vol. 113, No. 1, pp.743-754.

Wahjudi, D., Gan, S-S., Anggono, J. and Tanoto, Y.Y. (2018) 'Factors affecting purchase intention of remanufactured short life-cycle products', International Journal of Business and Society, Vol. 19, No. 2, pp.415-428. 
Wang, Y. and Hazen, B.T. (2016) 'Consumer product knowledge and intention to purchase remanufactured products', International Journal of Production Economics, Vol. 181, No. Part B, pp.460-469.

Wang, Y., Wiegerinck, V., Krikke, H. and Zhang, H. (2013) 'Understanding the purchase intention towards remanufactured product in closed-loop supply chains: an empirical study in China', International Journal of Physical Distribution \& Logistics Management, Vol. 43, No. 10, pp.866-888. 